This is an author produced version of a paper published in CAB REVIEWS: PERSPECTIVES IN AGRICULTURE, VETERINARY SCIENCE, NUTRITION AND NATURAL RESOURCES. This paper has been peer-reviewed and is proof-corrected, but does not include the journal pagination.

Citation for the published paper:

Åhman I., Glinwood R., Ninkovic V. (2010) The potential for modifying plant volatile composition to enhance resistance to arthropod pests. $C A B$ Reviews: Perspectives in Agriculture, Veterinary Science, Nutrition and Natural Resources. Volume: 5 Number: 6, pp 10.

http://www.cabi.org/cabreviews/default.aspx?LoadModule=Review\&Re view $\mathrm{ID}=126125 \&$ site $=167 \&$ page $=1486$

Access to the published version may require journal subscription.

Published with permission from: CAB International

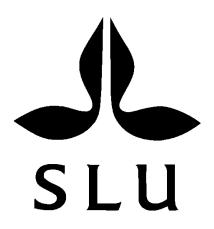





\title{
The potential for modifying plant volatile composition to enhance resistance to
}

\section{arthropod pests}

Inger $\AA$ hman ${ }^{1}$, Robert Glinwood ${ }^{2}$ and Velemir Ninkovic ${ }^{2}$

${ }^{1}$ Swedish University of Agricultural Sciences, Faculty of Landscape Planning, Horticulture

and Agricultural Science, Box 104, SE-230 53 Alnarp, Sweden

${ }^{2}$ Swedish University of Agricultural Sciences, Department of Ecology, Box 7044, SE-750 07

Uppsala, Sweden

Corresponding author: Inger.Ahman@ltj.slu.se

\begin{abstract}
Plant volatiles provide herbivorous arthropods with information that allows them to discriminate between host and non-host plants. Volatiles may also indicate plant stress status, and natural enemies can use herbivore-induced plant volatiles as cues for prey location.

Neighbouring plants may also make use of volatile cues to prepare for herbivore attack. Since both constitutive and inducible plant volatile emissions can be modified by plant breeding, the possibility exists to improve plant resistance against important pests both directly and indirectly via improved biological control. So far this approach has been tested only in the realm of research, predominantly using transgenic Arabidopsis with modified composition of terpenoids or $\mathrm{C}_{6}$ green leaf compounds. However several studies have shown that it is indeed possible both to reduce herbivory and enhance natural enemy attraction simultaneously. If such effects can be translated into increased and more stable yields in important crops, this strategy might be explored by the plant breeding industry and eventually become available to plant growers in the form of resistant cultivars. There are however ecological challenges associated with this approach, and the modified plant volatile composition should preferably be inducible specifically by the target pests, or by field application of specific elicitors based on forecasts of pest attack.
\end{abstract}




\section{Keywords}

Insect, plant breeding, induced resistance, natural enemies, indirect plant defense

\section{Review methodology}

This review focuses mainly on the effects of plant volatiles on herbivorous insects (pollinators excluded), because insects are prominent pests in agriculture and horticulture, but also because there is more information about insects and their host relationships than about other pests of plants. However, much of our reasoning may also apply to other herbivores, certainly to mites. In addition to direct effects of plant volatiles on herbivores, we cover the role of plant volatiles for the natural enemies of the herbivores, a type of 'indirect resistance' (cf. indirect defence, sensu Dicke and Sabelis [1]). Behavioural effects of volatiles on herbivores and natural enemies are emphasised. Furthermore, we discuss how plant volatiles may affect the induction of direct and indirect resistance in neighbouring plants. The use of "neighbour volatiles' in pest control through trap cropping or 'push-pull' are omitted from this review. We searched for information via ISI Web of knowledge 'All databases' (topic "volatile* AND resistance", refined by Document type "Review or book" and topic "plant"), and ISI Web of Science (topic volatile* AND breeding AND (pest OR insect), databases SCI-EXPANDED, SSCI, A\&HCI). Additionally, we scanned review journals for recent articles related to our topic. We also used references from the articles obtained by these methods to find additional relevant information.

\section{Introduction}

Plant chemistry is a major determinant for host use by herbivorous arthropods. For most herbivores, host specialisation is the rule, and secondary chemistry is commonly shared 
among host plants, even if they are from different taxa [2]. One example of this is Pieris spp. using various brassicaceaous species as hosts but also species of Tropaeolaceae and Resedaceae, all three plant families characterised by the content of glucosinolates $[3,4]$. Host plant chemicals influencing host acceptance can be nutritional factors connected with primary metabolism, internal secondary metabolites, or substances expressed on plant surface layers. Insects may use all of these as cues for host acceptance. However plants also release volatile substances into the atmosphere, making them chemically detectable to other organisms from a distance. Since these chemicals can indicate a plant's identity and status, it is not surprising that both insects and other plants have evolved responses to them.

\section{Role of volatiles in host finding and use}

Herbivorous insects can use plant volatiles for long-range host plant location. Over shorter distances, plant volatiles can attract or repel insects searching for hosts for feeding or oviposition [5]. In some cases, host odour may cause a mere arousing effect leading to higher activity in general, which in turn leads to a higher rate of host encounters and landings (cf. [6]. Less is known about how volatiles affect the herbivore after plant contact and once feeding or oviposition has started $[2,7]$.

As well as providing insects with information allowing discrimination between hosts and nonhosts [8,9], volatiles may indicate plant stress status [10]. Apart from these behavioural effects on the herbivore, volatiles may have physiological, toxic effects as well [11-14]. In plant resistance terminology the latter mode of action is called antibiosis, whereas an adverse effect on normal host finding and acceptance behaviour is called antixenosis [15]. 
Herbivore feeding [16,17] and oviposition [18] may in turn modify the plants' volatile profiles by the induction of chemical blends associated with tissue damage and induced plant defences. These volatiles can themselves be involved in induced direct resistance against the attacking herbivore, and may also serve to attract the herbivore's natural enemies $[19,20]$. The latter process can be considered an integral part of plant resistance against herbivory and has been called indirect defence [1], although in many cases it is not yet clear whether it increases plant fitness [21]. Natural enemies may also be attracted by volatiles apparently released constitutively by plants. For example, olfactory preferences for different plant cultivars have been reported for aphid parasitoids in barley [22] and cabbage [23], when the plants were visibly undamaged.

\section{Possibilities for modifying volatile profiles of plants}

A wealth of volatile compounds exists in the plant kingdom, and so far more than 1700 have been identified in leaves, roots, flowers and fruits [24]. Some are common to most plants, such as certain $\mathrm{C}_{6}$ alcohols and aldehydes found in green leaves and shoots (GLVs; [25]), and methyl salicylate, methyl jasmonate and ethylene involved in stress signalling within and between plant individuals [26-28]. Others are typical of certain plant taxa, for example isothiocyanates and nitriles that are breakdown products from glucosinolates in Brassicaceae [29], and sulfides that are characteristic of onions, Allium spp. [30]. Among the terpenoids, there is a wealth of volatile compounds [31], many of which typify certain taxa, such as menthol in Mentha spp. [32].

Conventional breeding is one route to modifying plant volatile profiles so that they become less attractive to a pest or more attractive to the pest's natural enemies (Figure 1). More recently the possibility has arisen to use knowledge on genetic regulation of volatile synthesis 
or breakdown in plants for targeted mutation or transformation [10,33,34]. One exciting field of research that may be exploited focuses on the role of plant volatiles in inducing higher levels of direct and indirect resistance in neighbouring plants [35-39]; Figure 1).

\section{Volatile modification via conventional breeding}

Conventional plant resistance breeding has most often been carried out without any deeper knowledge about the causes for increased resistance, i.e. which plant traits are being modified by selection for plants with lower levels of herbivore attack and damage. To our knowledge, there is no example of deliberate selection for a modified plant volatile profile to enhance pest resistance that has resulted in commercial release of a resistant cultivar. This is not to say that no changes in plant volatile emissions have taken place as a result of selection for resistance to pests. However, with increasing knowledge about which plant traits are important for host selection, more targeted breeding is possible. Indeed, volatile attractants or repellents have been identified in several crops including sweetpotato [40], grapevine [41], and maize [42] where they have been suggested to be used as selection criteria for improved direct or indirect resistance to pests.

A prerequisite for plant breeding is that genetic variation for the trait exists. Within the plant kingdom there is certainly great variation in volatile emissions. However, only a limited number of the more specific volatiles are possible to exploit through conventional breeding due to crossing barriers between the source plant and the crop. Intra-specific genetic variation in volatile emission rates and composition, giving the possibility of cross breeding, exists within cultivated species as exemplified by cotton [43], rice [44,45], cabbage [46], sweetpotato [40], pear [47], maize [48], wheat [49], carrot [50], and thyme [51]. 
Intra-specific differences in volatile emission may exist in the chemical components, concentrations or total amounts. Presumably the pest would have to respond differently to a modified blend for this to be useful as a resistance trait. Herbivore responsiveness to specific host plant volatile blends has indeed been shown. Visser and Avé [52] were the first to show that the ratio of ubiquitous compounds in a plant volatile blend may be more important for herbivore attraction than single compounds more typical of the host species. The Colorado potato beetle was attracted to the specific blend of $\mathrm{C}_{6}$ alcohols and aldehydes (GLVs) in potato, and attraction was lost if any of the components was increased in concentration [52]. Since that first evidence, there have been more examples of herbivore responses to volatile blends $[5,41,53,54]$. This may be encouraging for the modification of crop volatile emission to increase anti-herbivore effects, since relatively minor changes in the volatile profile may be enough to disrupt the insect's response. The robustness of this approach however would depend on the degree of behavioural plasticity and evolutionary adaptation shown by the herbivore.

The natural enemies of herbivores can also respond to plant volatile composition, and this has been most widely studied with herbivore-damaged plants $[37,55]$. There is intra-specific genetic variation for herbivore-induced volatile emissions, as demonstrated in common bean [16], apple [56], cotton [57], cabbage [46], wild tobacco [58], maize [48,59,60], pear [47], carrot [50] and rice [61]. This variation may be used for breeding for improved indirect resistance. For example, it may be possible to breed for improved indirect resistance to western corn rootworm (Diabrotica virgifera virgifera) via the entomopathogenic nematode Heterorhabditis megidis in maize by exploiting existing intra-specific variation in $(E)-\beta$ caryophyllene production in damaged roots. Maize varieties that produce this sesquiterpene in 
response to Diabrotica feeding had a five-fold higher rate of Diabrotica larvae with nematode infestation than a variety without the compound [42].

Perhaps the biggest obstacle to conventional breeding is finding cheap and precise selection methods for specific volatiles or volatile blends [62]. Ideally selections should be made by non-destructive analysis of single plants, in order to make selections in early generations after crossing. However, reproducible sampling and analyses of plant volatiles is not trivial due to relatively low rates of emission, variability between plant individuals [63] and the need for advanced collection and analysis techniques [64]. An option might be to try and find DNAbased markers for volatile production and base selection on these. For a very precise selection, such markers should be placed in specific genes critical for production of a particular volatile or blend end product. Plant volatile biosynthesis is an active research field, but still less than $10 \%$ of the underlying genes have probably been identified [10].

\section{Volatile modification via transformation or mutation}

Detailed knowledge on genetic regulation of volatile synthesis and breakdown [10] may also be used for breeding via mutation or transformation techniques. The latter would have the additional advantage of allowing gene introductions that are not otherwise possible, due to crossing barriers between the gene source and the plant material of agronomic interest. To our knowledge, such a transgenic approach for volatile modification has not yet been used for practical breeding purposes and production of commercial varieties in any crop. However there are many examples of transgenic plants with modified volatile profiles that have been developed to study the role of volatile cues in interactions with herbivores and their natural enemies (Table 1). 
One class of compounds with well described effects on herbivores and their natural enemies are the terpenoids. Lima beans release the homo-terpene 4,8-dimethyl-1,3(E),7-nonatriene (DMNT) when attacked by spider mites [1]. By overexpressing a strawberry terpene synthase in Arabidopsis, this compound and its precursor (3S)-(E)-nerolidol were produced by nonattacked plants. The transformed Arabidopsis plants were more attractive to the predatory mite Phytoseiulus persimilis than non-transformed plants [65]. Similarly, Arabidopsis equipped with a specific maize terpene synthase gene causing elevated levels of $(E)-\beta-$ farnesene and $(E)$ - $\alpha$-bergamotene was more attractive to the parasitic wasp Cotesia marginiventris than was its non-transformed counterpart. The parasitoid response was equivalent to that to volatiles from herbivore-damaged maize [66]. In another example, the aphid parasitoid Diaeretiella rapae spent more time on Arabidopsis producing elevated levels of the aphid alarm pheromone component $(E)-\beta$-farnesene due to the addition of a $(E)-\beta$ farnesene synthase gene from Mentha [67]. Nematode-mediated control of the western corn rootworm was substantial in a field trial with a maize line naturally lacking the nematode attractant $(E)$ - $\beta$-caryophyllene but with emissions restored after transformation with an $(E)-\beta$ caryophyllene synthase gene under the control of a constitutive promoter [68]. The examples above suggest that volatile cues with ecological relevance for natural enemies can depend on single genes, something which might simplify the modification of plant volatile signalling.

Herbivore reactions to modified terpenoid compositions have also been found, for example in response to transgenically upregulated concentrations of linalool and nerolidol [69], or (E)- $\beta$ farnesene [67] in Arabidopsis. In relation to both plants, attraction of the aphid Myzus persicae was reduced. In the case of $(E)$ - $\beta$-farnesene, the effect may be explained by the fact that this compound is a component of the alarm pheromone produced by several aphid species [67]. Caterpillars of the tobacco hornworm, Manduca sexta, were deterred from feeding on 
transgenic tobacco emitting isoprene [70] or patchoulol [71], both of which are novel to tobacco. Isoprene is not released by host plants of the diamond back moth, Plutella xylostella, and transgenic Arabidopsis emitting this compound repelled the moth's natural enemy Diadegma semiclausum. However, two herbivores specialised on brassicaceous hosts, $P$. xylostella and Pieris rapae, were indifferent to the novel plant trait [72].

$\mathrm{C}_{6}$ green leaf volatiles (GLVs) are present in intact plants but their emission can increase dramatically in response to wounding [73]. Like certain terpenoids, these compounds are used by natural enemies as cues to aid location of plants infested by their herbivore hosts. GLVs are synthesized via the lipoxygenase/hydroperoxide pathway [10]. By overexpressing a hydroperoxide lyase (HPL) gene from bell pepper in Arabidopsis, plants produced more (Z)3-hexenal than the wild-type upon feeding by larvae of Pieris rapae [74]. Such plants were also more attractive to the herbivore's parasitoid Cotesia glomerata.

While many terpenoids and GLVs are common to different plant taxa, volatiles with a more restricted occurrence have been less exploited for transgenic modification of plants. However, Arabidopsis with a modified route of glucosinolate breakdown upon tissue disruption has been developed. The non-transgenic ecotype produces mainly isothiocyanates while the transgene produces mainly nitriles, with the gene responsible taken from another Arabidopsis ecotype. Herbivorous larvae of the lepidopteran P. rapae excrete nitriles in their faeces upon glucosinolate ingestion. Thus nitriles may be a cue for its parasitoid Cotesia rubecula, and indeed this natural enemy was more attracted to the nitrile Arabidopsis type than to the isothiocyanate type. Further, $P$. rapae females avoided these plants for oviposition, possibly because nitrile emission indicated that they were already occupied by conspecific larvae [75]. 
Down-regulation of volatile-related genes is possible via mutations in those genes or transformation of plants with antisense constructs or via cosuppression [33]. The use of chemically induced mutations in breeding has seen a revival thanks to increasing knowledge about essential genes in metabolic pathways, and new multiplex screening techniques to target plant lines with mutations in the desired genes [76]. Another recent type of mutation approach is DNA tag insertions, producing loss-of-function-mutants [77].

There are some reports on mutated plants and volatile-mediated effects on herbivores and their natural enemies. However, even though Lotus japonicus mutants had a different terpenoid composition after spider mite infestation than the wild-type, they still attracted the predatory mite $P$. persimilis to the same extent [78]. The aphid parasitoid $D$. rapae was used as a biosensor for volatiles induced by the aphid M. persicae in four Arabidopsis mutants with modifications in signalling pathways known to be important for plant responses to insect and pathogen attack. The parasitoid's response suggested that both the octadecanoid pathway, with jasmonic acid as a key signalling compound, and salicylic acid are important for the aphid-induced volatile attraction [79]. Similarly, tomato mutants with jasmonate deficiencies had lower levels of herbivore-induced terpenoids, attracted fewer predatory mites; and were more suitable or attractive as hosts for the herbivorous lepidopterans Spodoptera exigua and M. sexta, and the whitefly Bemisia tabaci $[80,81]$.

Down-regulation of genes can also be obtained by introducing gene constructs that interfere with RNA. When the gene construct produces RNA in the opposite (antisense) direction to the normal targeted gene, considerably reduced protein production can result [33]. Using such methods, plants low in terpenoids and GLVs have been developed and tested for effects on herbivores and their natural enemies. Arabidopsis and wild tobacco (Nicotiana attenuata) 
with decreased levels of herbivore-inducible GLVs were significantly less attractive to $C$. glomerata, the parasitoid of P. rapae [74], and the generalist predatory bug Geocoris pallens [82], respectively.

Herbivores can also be affected by decreased GLV levels. The aphid M. persicae was more fecund when feeding on potato with GLVs downregulated by a bell pepper HPL gene in antisense position than when feeding on the nontransformed plants [83]. On the contrary, $N$. attenuata plants with reduced levels of herbivore-induced GLVs supported lower larval feeding and performance in M. sexta in a laboratory study [84] and accumulated fewer Epitrix hirtipennis flea beetles in the field [82]. However there was no effect of GLVs on the aphid M. persicae and the leaf miner Liriomyza trifolii in a mutant Arabidopsis with GLV production and induction restored by transformation [85]. Both the mutated line and its transformed counterpart were devoid of the competing branch of the defense pathway that is involved in jasmonate production, thus reducing the risk for confounding effects. The aphid parasitoid Aphidius colemani was attracted to the elevated levels of GLVs in these plants [85] as was the case with the other natural enemy/plant combinations discussed above.

Transgenic $N$. attenuata devoid of herbivore-induced terpenoids received more damage by Empoasca leaf hoppers, however in this case plants also had reductions in other defencerelated compounds [86]. The predator G. pallens was less attracted to these plants than to the wild-type [82].

In the examples above, the transgenes were regulated by constitutive or herbivore-inducible promoters (Table 1). Both mechanical damage itself and certain compounds in herbivore oral $[87,88]$ and oviposition secretions [18] can induce plant volatile production. The resulting 
volatile blends differ depending on the inducing agents [89]. Thus, with better knowledge of plant receptors and the regulatory elements of the subsequently induced genes, it might be possible to combine these elements with novel genes influencing plant volatile composition as a result of a specific herbivore attack. It would be particularly useful to express plant receptors for compounds associated with eggs and oviposition [18], since these may cause early defence induction before feeding damage occurs.

\section{Resistance induction via plant volatiles}

Plants respond to feeding and oviposition by herbivorous insects in a number of ways, among them by production of specific volatiles [21]. Some of these compounds function as plant hormones causing unattacked leaves of the same plant to change their chemistry by aerial induction [90-92]. Herbivore-induced volatiles may thus primarily represent a within-plant signalling system that allows rapid damage recognition by the plant $[28,93]$. However, these induced volatiles can also affect resistance to herbivores and attraction of their natural enemies in neighbouring plants [35-39, 94, 95]. Such chemical eavesdropping may provide plants with early warning of herbivore threat [96], while priming defences $[39,93,97,98]$ rather than directly inducing defence compounds may conserve plant resources [99] and protect against self-toxicity [cf. 100].

Volatile interactions occur not only between herbivore-damaged plants, apparently undamaged plants have also been found to induce responses in their neighbours [101]. This has been studied using the aphid Rhopalosiphum padi as a biosensor and demonstrated in certain combinations of different emitter and receiver barley genotypes. After screening hundreds of pair-wise combinations of barley varieties and breeding lines, certain patterns emerged. In a selection of cultivars spanning over 100 years of breeding, there was a tendency 
that older varieties were induced to a higher degree of antixenosis resistance than the more recent varieties, whereas this age relationship was reversed for resistance eliciting capacity (Kellner et al. in review). The aphid predator Coccinella septempunctata and the aphid parasitoid A. colemani responded with increased attraction to volatile-induced changes in certain barley-barley combinations that were also induced to become less attractive to the host aphid [22]. Further, barley genotypes selected as more resistant to aphids in resistance screening tests for aphid growth were generally more responsive to plant volatile induction [102]. Thus there is potential for further improving this type of plant neighbour-induced resistance and biological control by breeding; and to grow inducing and responding plant genotypes together in the field [103]. The potential also exists to identify the active volatile cues and apply them in crops as chemical elicitors [cf. 104-106] or as natural enemy attractants [107].

Elicitor applications in various crops, directed at induced resistance to diseases and arthropod pests, have mainly involved homologues of salicylic and jasmonic acids [108]. While application has commonly led to reductions in pest or disease attack, proportionally increased yields compared to controls have not been realised. However, Vallad and Goodman [108] suggest that breeding plants with improved induced defence and minimised defence costs is possible since there is intra-specific variation in both traits. Also, when signal compounds from insect oviposition, feeding, and neighbouring plants $[18,87,88,93]$, and their molecular recognition by responding plants become better known, the way will be open for combinations of specific artificial elicitors, promoters and novel genes useful for gene constructs aimed at early, strong and specific induction of plant volatiles. 


\section{Challenges for durable effects of volatile modifications}

Monoculture is the norm for commercially grown crops. In this context, for an antixenotic resistance trait that only affects behaviour, there is a risk that a herbivore will eventually accept a plant that initially was less attractive or acceptable. As the pressure to feed or oviposit increases, and the insect's behaviour becomes less discriminatory, responses to volatiles or blends may decrease, particularly since plants have a number of other traits guiding host search and acceptance. Behavioural adaptation can also occur within an insect's lifetime via learning, and studies have shown that insect responses to plant volatiles, particularly in generalist natural enemies, can be modified by learning $[109,110]$. In some cases, full responses to herbivore-induced plant volatile blends may be formed only after associative learning [111], meaning that positive stimuli in the form of herbivore prey would need to be present in the habitat.

Apart from the risk that reduced attractiveness is of short duration due to lack of preferred hosts, there is also the risk for genetic selection for insect individuals that are less specific in their responses to host odours. Thus, herbivores may be able to overcome plant volatile based resistance traits just as they have done with other non-volatile ones [e.g. 112]. For this reason, it would be more favourable if the change in host volatiles affects not only insect behaviour via antixenosis but is also coupled with an antibiosis trait, such as toxicity of the modified volatile blend itself [cf. 113]. However there are far fewer studies addressing effects of plant volatiles on herbivore performance than on herbivore behaviour. Another solution for slowing down genetic adaptation to a modified host odour might be to express the trait only when the host is most vulnerable or when the pest is most abundant. To have volatile-related genes expressed only when herbivore abundance is high reduces the potential exposure time and thereby some of the selection pressure for counter adaptation by the pest. If a temporary 
volatile change additionally, or exclusively, affects natural enemies of the herbivore, this indirect resistance could even select for the pest to avoid the 'enemy enriched space' of the modified plant. This may in turn select against natural enemies responding to the volatiles, a risk which is however more likely when attractive volatiles are released constitutively by plants without the reward of prey [114].

\section{Conclusions and future directions}

A transgene approach to plant volatile modification for enhanced resistance to arthropod pests enables a more drastic change in volatile composition, and probably faster cultivar development, in comparison with conventional breeding [115]. Further, with transgenic resistance it will be possible to choose inducible promoters with tissue-specific expression, reducing risks for plant self-toxicity [cf. 100] and decreasing metabolic costs for volatile production. Increased understanding of signal compounds and their molecular recognition by receiving plants will allow the development of specific elicitors; and promoters used for gene constructs for modification of volatile emission. During the development of new transgenic plants, it will be necessary to study effects on other organisms in the food web $[89,115,116]$, and to establish that introduced changes do not reduce the quality of the crop as food or feed. Finally, it is important that impacts of new cultivars on pest populations and yields are sufficient that the plant breeding industry decides to invest in their development and farmers choose to grow them. 


\section{Acknowledgements}

This work was financially supported by Mistra through the PlantComMistra program. Lisbeth Jonsson, and two anonymous referees are thanked for help in reviewing and improving our manuscript.

\section{References}

\begin{tabular}{|c|c|}
\hline 1. & $\begin{array}{l}\text { Dicke M, Sabelis MW. How plants obtain predatory mites as bodyguards. Netherlands } \\
\text { Journal of Zoology 1988;38:148-65. }\end{array}$ \\
\hline 2. & $\begin{array}{l}\text { Schoonhoven LM, van Loon JJA, Dicke M. Insect-Plant Biology. } 2^{\text {nd }} \text { ed. Hampshire, } \\
\text { Great Britain: Oxford University Press; } 2005 .\end{array}$ \\
\hline 3. & $\begin{array}{l}\text { Verschaffelt E. The cause determining the selection of food in some herbivorous } \\
\text { insects. Proceedings of the Koninklijke Nederlandse Akademie van Wetenschappen } \\
\text { 1910;13:536-42. }\end{array}$ \\
\hline 4. & $\begin{array}{l}\text { Rodman JE, Soltis PS, Soltis DE, Sytsma KJ, Karol KG. Parallel evolution of } \\
\text { glucosinolate biosynthesis inferred from congruent nuclear and plastid gene } \\
\text { phylogenies. American Journal of Botany 1998;85:997-1006. }\end{array}$ \\
\hline 5. & $\begin{array}{l}\text { Bruce TJA, Wadhams LJ, Woodcock CM. Insect host location: a volatile situation. } \\
\text { Trends in Plant Science 2005;10:269-74. }\end{array}$ \\
\hline 6. & $\begin{array}{l}\text { Feeny P, Städler E, Åman I, Carter M. Effects of plant odor on oviposition by the } \\
\text { black swallowtail butterfly, Papilio polyxenes (Lepidoptera: Papilionidae). Journal of } \\
\text { Insect Behavior 1989;2:803-27. }\end{array}$ \\
\hline 7. & $\begin{array}{l}\text { Städler E. Plant chemical cues important for egg deposition by herbivorous insects. In: } \\
\text { Hilker M, Meiners T, editors. Chemoecology of insect eggs and egg deposition. Berlin, } \\
\text { Germany: Blackwell Publishing; 2002. p. 171-204. }\end{array}$ \\
\hline 8. & $\begin{array}{l}\text { Nottingham SF, Hardie J. Flight behaviour of the black bean aphid, Aphis fabae, and } \\
\text { the cabbage aphid, Brevicoryne brassicae, in host and non-host plant odour. } \\
\text { Physiological Entomology 1993;18:389-94. }\end{array}$ \\
\hline 9. & $\begin{array}{l}\text { Campbell SA, Borden JH. Additive and synergistic integration of multimodal cues of } \\
\text { both hosts and non-hosts during host selection by woodboring insects. Oikos } \\
2009 ; 118: 553-63 \text {. }\end{array}$ \\
\hline 10. & $\begin{array}{l}\text { Dudareva N, Negre F, Nagegowda DA, Orlova I. Plant volatiles: Recent advances and } \\
\text { future perspectives. Critical Reviews in Plant Sciences 2006;25:417-40. }\end{array}$ \\
\hline 11. & $\begin{array}{l}\text { Ahman I. Toxicities of host secondary compounds to eggs of the Brassica specialist } \\
\text { Dasineura brassicae. Journal of Chemical Ecology 1986;12:1481-88. }\end{array}$ \\
\hline 12. & $\begin{array}{l}\text { Coats JR, Karr LL, Drewes CD. Toxicity and neurotoxic effects of monoterpenoids in } \\
\text { insects and earthworms. In: Hedin PA, editor. Naturally occurring pest bioregulators. } \\
\text { Washington DC, USA: American Chemical Society; 1991. p. 305-16. }\end{array}$ \\
\hline 13. & $\begin{array}{l}\text { Rice PJ, Coats JR. Insecticidal properties of several monoterpenoids to the house fly } \\
\text { (Diptera: Muscidae), red flour beetle (Coleoptera: Tenebrionidae), and southern corn } \\
\text { rootworm (Coleoptera: Chrysomelidae). Journal of Economic Entomology } \\
\text { 1994;87:1172-9. }\end{array}$ \\
\hline 14. & Choi W-S, Park B-S, Lee Y-H, Jang DY, Yoon HY, Lee S-E. Fumigant toxicities of \\
\hline
\end{tabular}




\begin{tabular}{|c|c|}
\hline & $\begin{array}{l}\text { essential oils and monoterpenes against Lycoriella mali adults. Crop Protection } \\
\text { 2006;25:398-401. }\end{array}$ \\
\hline 15. & $\begin{array}{l}\text { Smith CM. Plant resistance to insects - A fundamental approach. New York, USA: } \\
\text { John Wiley \& Sons; } 1989 .\end{array}$ \\
\hline 16. & $\begin{array}{l}\text { Dicke M, Sabelis MW, Takabayashi J, Bruin J, Posthumus MA. Plant strategies of } \\
\text { manipulating predator-prey interactions through allelochemicals: prospects for } \\
\text { application in pest control. Journal of Chemical Ecology 1990;16:3091-118. }\end{array}$ \\
\hline 17. & $\begin{array}{l}\text { Dicke M, van Beek TA, Posthumus MA, Ben Dom N, van Bokhoven H, de Groot AE. } \\
\text { Isolation and identification of volatile kairomone that affects acarine predator-prey } \\
\text { interactions - involvement of host plant in its production. Journal of Chemical Ecology } \\
\text { 1990;16:381-96. }\end{array}$ \\
\hline 18. & $\begin{array}{l}\text { Hilker M, Meiners T. Early herbivore alert: insect eggs induce plant defense. Journal of } \\
\text { Chemical Ecology 2006;32:1379-97. }\end{array}$ \\
\hline 19. & $\begin{array}{l}\text { Kessler A, Baldwin IT. Defensive function of herbivore-induced plant volatile } \\
\text { emissions in nature. Science 2001;291:2141-4. }\end{array}$ \\
\hline 20. & $\begin{array}{l}\text { Pickett JA, Glinwood RT. Chemical ecology. In: van Emden HF, Harrington R, editors. } \\
\text { Aphids as crop pests. Trowbridge, UK: CAB International; 2007. p. 235-60. }\end{array}$ \\
\hline 21. & Heil M. Indirect defence via tritrophic interactions. New Phytologist 2008;178:41-61. \\
\hline 22. & $\begin{array}{l}\text { Glinwood R, Ahmed E, Qvarfordt E, Ninkovic V, Pettersson J. Airborne interactions } \\
\text { between undamaged plants of different cultivars affect insect herbivores and natural } \\
\text { enemies. Arthropod-Plant Interactions } 2009 ; 3: 215-24 \text {. }\end{array}$ \\
\hline 23. & $\begin{array}{l}\text { Kalule T, Wright DJ. The influence of cultivar and cultivar-aphid odours on the } \\
\text { olfactory response of the parasitoid Aphidius colemani. Journal of Applied Entomology } \\
\text { 2004;128:120-5. }\end{array}$ \\
\hline 24. & $\begin{array}{l}\text { Knudsen JT, Gershenzon J. The chemical diversity of floral scent. In: Dudareva N, } \\
\text { Pichersky E, editors. Biology of floral scent. Boca Raton, FL, USA: CRC Press Taylor } \\
\text { \& Francis Group; 2006. p. 27-52. }\end{array}$ \\
\hline 25. & $\begin{array}{l}\text { Visser JH, van Straten S, Maarse H. Isolation and identification of volatiles in the } \\
\text { foliage of potato, Solanum tuberosum, a host plant of the Colorado beetle, Leptinotarsa } \\
\text { decemlineata. Journal of Chemical Ecology 1979;5:11-23. }\end{array}$ \\
\hline 26. & $\begin{array}{l}\text { Farmer EE, Ryan CA. Interplant communication: Airborne methyl jasmonate induces } \\
\text { synthesis of proteinase inhibitors in plant leaves. Proceedings of the National Academy } \\
\text { of Science of the United States of America 1990;87:7713-16. }\end{array}$ \\
\hline 27. & $\begin{array}{l}\text { Shulaev V, Silverman P, Raskin I. Airborne signalling by methyl salicylate in plant } \\
\text { pathogen resistance. Nature 1997;385:718-21. }\end{array}$ \\
\hline 28. & $\begin{array}{l}\text { Heil M, Ton J. Long-distance signalling in plant defence. Trends in Plant Science } \\
\text { 2008;13:264-72. }\end{array}$ \\
\hline 29. & $\begin{array}{l}\text { Cole RA. Isothiocyanates, nitriles and thiocyanates as products of autolysis of } \\
\text { glucosinolates in Cruciferae. Phytochemistry } 1976 ; 15: 759-62 \text {. }\end{array}$ \\
\hline 30. & $\begin{array}{l}\text { Schulz H, Kruger H, Liebmann J, Peterka H. Distribution of volatile sulfur compounds } \\
\text { in an interspecific hybrid between onion (Allium cepa L.) and leek (Allium porrum L.). } \\
\text { Journal of Agricultural and Food Chemistry 1998;46:5220-4. }\end{array}$ \\
\hline 31. & Connolly JD, Hill RA. Dictionary of terpenoids. London, UK: Chapman \& Hall, 1991. \\
\hline 32. & $\begin{array}{l}\text { Croteau RB, Davis EM, Ringer KL, Wildung MR. ()-Menthol biosynthesis and } \\
\text { molecular genetics. Naturwissenschaften 2005;92:562-77. }\end{array}$ \\
\hline 33. & $\begin{array}{l}\text { Roda AL, Baldwin IT. Molecular technology reveals how the induced direct defenses } \\
\text { of plants work. Basic and Applied Ecology } 2003 ; 4: 15-26 \text {. }\end{array}$ \\
\hline 34. & $\begin{array}{l}\text { Turlings TCJ, Ton J. Exploiting scents of distress: the prospect of manipulating } \\
\text { herbivore-induced plant odours to enhance the control of agricultural pests. Current }\end{array}$ \\
\hline
\end{tabular}




\begin{tabular}{|c|c|}
\hline & Opinion in Plant Biology 2006;9:421-7. \\
\hline 35. & $\begin{array}{l}\text { Bruin J, Dicke M. Chemical information transfer between wounded and unwounded } \\
\text { plants: backing up the future. Biochemical Systematics and Ecology 2001;29:1103-13. }\end{array}$ \\
\hline 36. & $\begin{array}{l}\text { Pichersky E, Gershenzon J. The formation and function of plant volatiles: perfumes for } \\
\text { pollinator attraction and defense. Current Opinion in Plant Biology 2002;5:237-43. }\end{array}$ \\
\hline 37. & $\begin{array}{l}\text { Dicke M, Agrawal AA, Bruin J. Plants talk, but are they deaf? Trends in Plant Science. } \\
\text { 2003;8:403-5. }\end{array}$ \\
\hline 38. & $\begin{array}{l}\text { Baldwin IT, Halitschke R, Paschold A, von Dahl CC, Preston CA. Volatile signaling in } \\
\text { plant-plant interactions: "Talking trees" in the genomics era. Science 2006;311:812-15. }\end{array}$ \\
\hline 39. & $\begin{array}{l}\text { Ton J, D'Alessandro M, Jourdie V, Jakab G, Karlen D, Held M, et al. Priming by } \\
\text { airborne signals boosts direct and indirect resistance in maize. The Plant Journal } \\
\text { 2006;49:16-26. }\end{array}$ \\
\hline 40. & $\begin{array}{l}\text { Wang Y, Kays SJ. Sweetpotato volatile chemistry in relation to sweetpotato weevil } \\
\text { (Cylas formicarius) behaviour. Journal of American Society for Horticultural Sciences } \\
\text { 2002;127:656-62. }\end{array}$ \\
\hline 41. & $\begin{array}{l}\text { Tasin M, Bäckman A-C, Bengtsson M, Ioratti C, Witzgall P. Essential host plant cues } \\
\text { in the grapevine moth. Naturwissenschaften 2006;93:141-4. }\end{array}$ \\
\hline 42. & $\begin{array}{l}\text { Rasmann S, Köllner TG, Degenhardt J, Hiltpold I, Toepfer S, Kuhlmann U, et al. } \\
\text { Recruitment of entomopathogenic nematodes by insect-damaged maize roots. Nature } \\
\text { 2005;434:732-7. }\end{array}$ \\
\hline 43. & $\begin{array}{l}\text { Elzen GW, Williams HJ, Vinson SB. Wind tunnel flight responses by hymenopterous } \\
\text { parasitoid Campoletis sonorensis to cotton cultivars and lines. Entomologia } \\
\text { Experimentalis et Applicata 1986;42:285-9. }\end{array}$ \\
\hline 44. & $\begin{array}{l}\text { Hernandez HP, Hsieh TC-Y, Smith CM, Fischer NH. Foliage volatiles of two rice } \\
\text { cultivars. Phytochemistry 1989;28:2959-62. }\end{array}$ \\
\hline 45. & $\begin{array}{l}\text { Rapusas HR, Bottrell DG, Coll M. Intraspecific variation in chemical attraction of rice } \\
\text { to insect predators. Biological Control 1996;6:394-400. }\end{array}$ \\
\hline 46. & $\begin{array}{l}\text { Geervliet JBF, Posthumus MA,Vet LEM, Dicke M. Comparative analysis of headspace } \\
\text { volatiles from different caterpillar-infested or unifested food plants of Pieris species. } \\
\text { Journal of Chemical Ecology 1997;23:2935-54. }\end{array}$ \\
\hline 47. & $\begin{array}{l}\text { Scutareanu P, Bruin J, Posthumus MA, Drukker B. Constitutive and herbivore-induced } \\
\text { volatiles in pear, alder and hawthorn trees. Chemoecology 2003;13:63-74. }\end{array}$ \\
\hline 48. & $\begin{array}{l}\text { Degen T, Dillmann C, Marion-Poll F, Turlings TCJ. High genetic variability of } \\
\text { herbivore-induced volatile emission within a broad range of maize inbred lines. Plant } \\
\text { Physiology 2004;135:1928-38. }\end{array}$ \\
\hline 49. & $\begin{array}{l}\text { Weaver DK, Buteler M, Hofland ML, Runyon JB, Nansen C, Talbert LE, et al. Cultivar } \\
\text { preferences of ovipositing wheat stem sawflies as influenced by the amount of volatile } \\
\text { attractant. Journal of Economic Entomology 2009;102:1009-17. }\end{array}$ \\
\hline 50. & $\begin{array}{l}\text { Nissinen A, Ibrahim M, Kainulainen P, Tiilikkala K, Holopainen JK. Influence of } \\
\text { carrot psyllid (Trioza apicalis) feeding or exogenous limonene or methyl jasmonate } \\
\text { treatment on composition of carrot (Daucus carota) leaf essential oil and headspace } \\
\text { volatiles. Journal of Agricultural and Food Chemistry 2005;53:8631-8. }\end{array}$ \\
\hline 51. & $\begin{array}{l}\text { Mewes S, Kruger H, Pank F. Physiological, morphological, chemical and genomic } \\
\text { diversities of different origins of thyme (Thymus vulgaris L.). Genetic Resources and } \\
\text { Crop Evolution 2008;55:1303-11. }\end{array}$ \\
\hline 52. & $\begin{array}{l}\text { Visser JH, Avé DA. General green leaf volatiles in the olfactory orientation of the } \\
\text { Colorado beetle, Leptinotarsa decemlineata. Entomologia Experimentalis et Applicata } \\
\text { 1978;24:738-49. }\end{array}$ \\
\hline 53. & Pinero JC, Dorn S. Synergism between aromatic compounds and green leaf volatiles \\
\hline
\end{tabular}




\begin{tabular}{|c|c|}
\hline & $\begin{array}{l}\text { rived from the host plant underlies female attraction in the oriental fruit moth. } \\
\text { tomologia Experimentalis et Applicata } 2007 ; 125: 185-94 \text {. }\end{array}$ \\
\hline 54. & $\begin{array}{l}\text { Webster B, Bruce T, Dufour S, Birkemeyer C, Birkett M, Hardie J, et al. Identification } \\
\text { of volatile compounds used in host location by the black bean aphid, Aphis fabae. } \\
\text { Journal of Chemical Ecology } 2008 ; 34: 1153-61 \text {. }\end{array}$ \\
\hline 55. & $\begin{array}{l}\text { Turlings TCJ, Tumlinson JH, Lewis WJ. Exploitation of herbivore-induced plant odors } \\
\text { by host-seeking parasitic wasps. Science 1990;250:1251-3. }\end{array}$ \\
\hline 56. & $\begin{array}{l}\text { Takabayashi J, Dicke M, Posthumus MA. Variation in composition of predator- } \\
\text { attracting allelochemicals emitted by herbivore-infested plants: relative influence of } \\
\text { plant and herbivore. Chemoecology 1991;2:1-6. }\end{array}$ \\
\hline 57. & $\begin{array}{l}\text { Loughrin JH, Manukian A, Heath RR, Tumlinson JH. Volatiles emitted by different } \\
\text { cotton varieties damaged by feeding beet armyworm larvae. Journal of Chemical } \\
\text { Ecology 1995;21:1217-27. }\end{array}$ \\
\hline 58. & $\begin{array}{l}\text { Halitschke R, Kessler A, Kahl J, Lorenz A, Baldwin IT. Ecophysiological comparison } \\
\text { of direct and indirect defenses in Nicotiana attenuata. Oecologia 2000;124:408-17. }\end{array}$ \\
\hline 59. & $\begin{array}{l}\text { ouinguené S, Degen T, Turlings TCJ. Variability in herbivore-induced odour } \\
\text { missions among maize cultivars and their wild ancestors (teosinte). Chemoecology } \\
001 ; 11: 9-16 .\end{array}$ \\
\hline 60. & $\begin{array}{l}\text { ritzsche Hoballah ME, Tamò C, Turlings TCJ. Differential attractiveness of induced } \\
\text { dors emitted by eight maize varieties for the parasitoid Cotesia marginiventris: is } \\
\text { dality or quantity important? Journal of Chemical Ecology 2002;28:951-68. }\end{array}$ \\
\hline 61. & $\begin{array}{l}\text { Lou Y, Hua X, Turlings TCJ, Cheng J, Chen X, Ye G. Differences in induced volatile } \\
\text { emissions among rice varieties result in differential attraction and parasitism of } \\
\text { Nilaparvata lugens eggs by the parasitoid Anagrus nilaparvatae in the field. Journal of } \\
\text { Chemical Ecology 2006;32:2375-87. }\end{array}$ \\
\hline 62. & $\begin{array}{l}\text { Dam NM, Poppy GM. Why plant volatile analysis needs bioinformatics - } \\
\text { tecting signal from noise in increasingly complex profiles. Plant Biology } \\
08 ; 10: 29-37 \text {. }\end{array}$ \\
\hline 63. & $\begin{array}{l}\text { areja M, Mohib A, Birkett MA, Dufour S, Glinwood RT. Multivariate statistics } \\
\text { opled to generalized linear models reveal complex use of chemical cues by a } \\
\text { arasitoid. Animal Behaviour 2009;77:901-9. }\end{array}$ \\
\hline 64. & $\begin{array}{l}\text { Tholl D, Boland W, Hansel A, Loreto F, Röse USR, Schnitzler J-P. Practical } \\
\text { approaches to plant volatile analysis. The Plant Journal 2006;45:540-60. }\end{array}$ \\
\hline 65. & $\begin{array}{l}\text { Kappers IF, Aharoni A, van Herpen TWJM, Luckerhoff LLP, Dicke M, Bouwmeester } \\
\text { HJ. Genetic engineering of terpenoid metabolism attracts bodyguards to Arabidopsis. } \\
\text { Science 2005;309:2070-2. }\end{array}$ \\
\hline 66. & $\begin{array}{l}\text { Schnee C, Köllner TG, Held M, Turlings TCJ, Gershenzon J, Degenhardt J. The } \\
\text { products of a single maize sesquiterpene synthase form a volatile defense signal that } \\
\text { attracts natural enemies of maize herbivores. Proceedings of the National Academy of } \\
\text { Sciences of the United States of America 2006;103:1129-34. }\end{array}$ \\
\hline 67. & $\begin{array}{l}\text { Beale MH, Birkett MA, Bruce TJA, Chamberlain K, Field LM, Huttly AK, et al. Aphid } \\
\text { alarm pheromone produced by transgenic plants affects aphid and parasitoid behaviour. } \\
\text { Proceedings of the National Academy of Sciences of the United States of America } \\
\text { 2006;103:10509-13. }\end{array}$ \\
\hline 68. & $\begin{array}{l}\text { Degenhardt J, Hiltpold I, Köllner TG, Frey M, Gierl A, Gershenzon J, et al. Restoring a } \\
\text { maize root signal that attracts insect-killing nematodes to control a major pest. } \\
\text { Proceedings of the National Academy of Sciences of the United States of America } \\
\text { 2009;106:13213-18. }\end{array}$ \\
\hline 69. & $\begin{array}{l}\text { Aharoni A, Giri AP, Deuerlein S, Griepink F, de Kogel W-J, Verstappen FWA, et al. } \\
\text { Terpenoid metabolism in wild-type and transgenic Arabidopsis plants. The Plant Cell }\end{array}$ \\
\hline
\end{tabular}




\begin{tabular}{|c|c|}
\hline & $2003 ; 15: 2866-84$ \\
\hline 70 . & $\begin{array}{l}\text { Laothawornkitkul J, Paul ND, Vickers CE, Possell M, Taylor JE, Mullineaux PM, et al. } \\
\text { Isoprene emissions influence herbivore feeding decisions. Plant, Cell and Environment } \\
\text { 2008;31:1410-15. }\end{array}$ \\
\hline 71. & $\begin{array}{l}\text { Wu S, Schalk M, Clark A, Miles RB, Coates R, Chappell J. Redirection of cytosolic or } \\
\text { plastidic isoprenoid precursors elevates terpene production in plants. Nature } \\
\text { Biotechnology } 2006 ; 24: 1441-7 \text {. }\end{array}$ \\
\hline 72. & $\begin{array}{l}\text { Loivamäki M, Mumm R, Dicke M, Schnitzler J-P. Isoprene interferes with the } \\
\text { attraction of bodyguards by herbaceous plants. Proceedings of the National Academy } \\
\text { of Sciences of the United States of America 2008;105:17430-35. }\end{array}$ \\
\hline 73. & $\begin{array}{l}\text { Farag MA, Fokar M, Zhang HAH, Allen RD, Paré PW. (Z)-3-Hexenol induces defense } \\
\text { genes and downstream metabolites in maize. Planta 2005;220:900-9. }\end{array}$ \\
\hline 74. & $\begin{array}{l}\text { Shiojiri K, Kishimoto K, Ozawa R, Kugimiya S, Urashimo S, Arimura G, et al. } \\
\text { Changing green leaf volatile biosynthesis in plants: An approach for improving plant } \\
\text { resistance against both herbivores and pathogens. Proceedings of the National } \\
\text { Academy of Sciences of the United States of America 2006; 103:16672-6. }\end{array}$ \\
\hline 75. & $\begin{array}{l}\text { Mumm R, Burow M, Bukovinszkine'Kiss G, Kazantzidou E, Wittstock U, Dicke M, et } \\
\text { al. Formation of simple nitriles upon glucosinolate hydrolysis affects direct and indirect } \\
\text { defense against the specialist herbivore, Pieris rapae. Journal of Chemical Ecology } \\
\text { 2008;34:1311-21. }\end{array}$ \\
\hline 76. & $\begin{array}{l}\text { Henikoff S, Till BJ, Comai L. Perspectives on Translational Biology - TILLING. } \\
\text { Traditional mutagenesis meets functional genomics. Plant Physiology 2004;135:630-6. }\end{array}$ \\
\hline 77. & $\begin{array}{l}\text { Kuromori T, Takahashi S, Kondou Y, Shinozaki K, Matsui M. Phenome analysis in } \\
\text { plant species using loss-of-function and gain-of-function mutants. Plant Cell } \\
\text { Physiology 2009;50:1215-31. }\end{array}$ \\
\hline 78. & $\begin{array}{l}\text { Ozawa R, Shimoda T, Kawaguchi M, Arimura G-I, Horiuchi J-I, Nishioka T, et al. } \\
\text { Lotus japonicus infested with herbivorous mites emits volatile compounds that attract } \\
\text { predatory mites. Journal of Plant Research 2000;113:427-33. }\end{array}$ \\
\hline 79. & $\begin{array}{l}\text { Girling RD, Madison R, Hassall M, Poppy GM, Turner JG. Investigations into plant } \\
\text { biochemical wound-response pathways involved in the production of aphid-induced } \\
\text { plant volatiles. Journal of Experimental Botany 2008;59:3077-85. }\end{array}$ \\
\hline 80. & $\begin{array}{l}\text { Thaler JS, Farag MA, Paré PW, Dicke M. Jasmonate-deficient plants have reduced } \\
\text { direct and indirect defences against herbivores. Ecology Letters 2002;5:764-74. }\end{array}$ \\
\hline 81. & $\begin{array}{l}\text { Sánchez-Hernández C, López MG, Délano-Frier JP. Reduced levels of volatile } \\
\text { emissions in jasmonate-deficient spr2 tomato mutants favour oviposition by insect } \\
\text { herbivores. Plant, Cell and Environment 2006;29:546-57. }\end{array}$ \\
\hline 82. & $\begin{array}{l}\text { Halitschke R, Stenberg JA, Kessler D, Kessler A, Baldwin IT. 2008. Shared signals - } \\
\text { "alarm calls" from plants increase apparency to herbivores and their enemies in nature. } \\
\text { Ecology Letters } 2008 ; 11: 24-34 \text {. }\end{array}$ \\
\hline 83. & $\begin{array}{l}\text { Vanncanneyt G, Sanz C, Farmaki T, Paneque M, Ortego F, Castañera P, et al. } \\
\text { Hydroperoxide lyase depletion in transgenic potato plants leads to an increase in aphid } \\
\text { performance. Proceedings of the National Academy of Sciences of the United States of } \\
\text { America 2001;98:8139-44. }\end{array}$ \\
\hline 84. & $\begin{array}{l}\text { Halitschke R, Ziegler J, Keinänen M, Baldwin IT. Silencing of hydroperoxide lyase } \\
\text { and allene oxide synthase reveals substrate and defense signaling crosstalk in Nicotiana } \\
\text { attenuata. The Plant Journal 2004;40:35-46. }\end{array}$ \\
\hline 85. & $\begin{array}{l}\text { Chehab EW, Kaspi R, Savchenko T, Rowe H, Negre-Zakharov F, Kliebenstein D, et al. } \\
\text { Distinct roles of jasmonates and aldehydes in plant-defense responses. PLoS ONE } \\
\text { 2008;3:e1904. }\end{array}$ \\
\hline 86. & Kessler A, Halitschke R, Baldwin IT. Silencing the jasmonate cascade: induced plant \\
\hline
\end{tabular}




\begin{tabular}{|c|c|}
\hline & defenses and insect populations. Science 2004;305:665-8. \\
\hline 87. & $\begin{array}{l}\text { Felton GW. Caterpillar secretions and induced plant responses. In: Schaller A, editor. } \\
\text { Induced plant resistance to herbivory. Dordrecht, The Netherlands: Springer } \\
\text { Science+Business Media B. V.; 2008. p. 369-87. }\end{array}$ \\
\hline 88. & $\begin{array}{l}\text { Tumlinson JH, Engelberth J. Fatty acid-derived signals that induce or regulate plant } \\
\text { defenses against herbivory. In: Schaller A, editor. Induced plant resistance to } \\
\text { herbivory. Dordrecht, The Netherlands: Springer Science+Business Media B. V.; } 2008 . \\
\text { p. 389-407. }\end{array}$ \\
\hline 89. & $\begin{array}{l}\text { Arimura G-I, Matsui K, Takabayashi J. Chemical and molecular ecology of herbivore- } \\
\text { induced plant volatiles: Proximate factors and their ultimate functions. Plant Cell } \\
\text { Physiology 2009;50:911-23. }\end{array}$ \\
\hline 90. & $\begin{array}{l}\text { Karban R, Shiojiri K, Huntzinger M, McCall AC. Damage-induced resistance in } \\
\text { sagebrush: Volatiles are key to intra- and interplant communication. Ecology } \\
\text { 2006;87:922-30. }\end{array}$ \\
\hline 91. & $\begin{array}{l}\text { Frost CJ, Appel HM, Carlson JE, De Moraes CM, Mescher MC, Schultz JC. Within- } \\
\text { plant signalling via volatiles overcomes vascular constraints on systemic signalling and } \\
\text { primes responses against herbivores. Ecology Letters } 2007 ; 10: 490-8 \text {. }\end{array}$ \\
\hline 92. & $\begin{array}{l}\text { Heil M, Bueno JCS. Within-plant signaling by volatiles leads to induction and priming } \\
\text { of an indirect plant defense in nature. Proceedings of the National Academy of } \\
\text { Sciences of the United States of America 2007;104:5467-72. }\end{array}$ \\
\hline 93. & $\begin{array}{l}\text { Heil M. Damaged-self recognition in plant herbivore defence. Trends in Plant Science } \\
\text { 2009;14:356-63. }\end{array}$ \\
\hline 94. & $\begin{array}{l}\text { Baldwin IT, Schultz JC. Rapid changes in tree leaf chemistry induced by damage: } \\
\text { evidence for communication between plants. Science } 1983 ; 221: 277-9 \text {. }\end{array}$ \\
\hline 95. & $\begin{array}{l}\text { Rhoades DF. Responses of alder and willow to attack by tent caterpillars and } \\
\text { webworms: evidence for pheromonal sensitivity of willows. In: Hedin PA, editor. Plant } \\
\text { resistance to insects. Washington, D.C., USA: ACS Symposium Series 208, American } \\
\text { Chemical Society; 1983. p. 55-68. }\end{array}$ \\
\hline 96. & $\begin{array}{l}\text { Baldwin IT, Kessler A, Halitschke R. Volatile signaling in plant-plant-herbivore } \\
\text { interactions: what is real? Current Opinion in Plant Biology 2002;5:351-4. }\end{array}$ \\
\hline 97. & $\begin{array}{l}\text { Bruce TJA, Matthes MC, Napier JA, Pickett JA. Stressful "memories" of plants: } \\
\text { Evidence and possible mechanisms. Plant Science 2007;173:603-8. }\end{array}$ \\
\hline 98. & $\begin{array}{l}\text { Frost CJ, Mescher MC, Dervinis C, Davis JM, Carlson JE, De Moraes CM. Priming } \\
\text { defense genes and metabolites in hybrid poplar by the green leaf volatile cis-3-hexenyl } \\
\text { acetate. New Phytologist 2008;180:722-34. }\end{array}$ \\
\hline 99. & $\begin{array}{l}\text { Van Hulten M, Pelser M, van Loon LC, Pieterse CMJ, Ton J. Costs and benefits of } \\
\text { priming for defense in Arabidopsis. Proceedings of the National Academy of Sciences } \\
\text { of the United States of America 2006;103:5602-7. }\end{array}$ \\
\hline 100. & $\begin{array}{l}\text { Gog L, Berenbaum MR, DeLucia EH, Zangerl AR. Autotoxic effects of essential oils } \\
\text { on photosynthesis in parsley, parsnip, and rough lemon. Chemoecology 2005;15:115- } \\
19 \text {. }\end{array}$ \\
\hline 101. & $\begin{array}{l}\text { Ninkovic V, Glinwood R, Pettersson J. Communication between undamaged plants by } \\
\text { volatiles: the role of allelobiosis. In: Baluška F, Mancuso S, Volkmann D, editors. } \\
\text { Communication in Plants: Neuronal Aspects of Plant Life, Vol. 28, Heidelberg, } \\
\text { Germany: Springer-Verlag; 2006. p. 421-34. }\end{array}$ \\
\hline 102. & $\begin{array}{l}\text { Ninkovic V, Ahman IM. Aphid acceptance of Hordeum genotypes is affected by plant } \\
\text { volatile exposure and is correlated with aphid growth. Euphytica } 2009 ; 169: 177-85 \text {. }\end{array}$ \\
\hline 103. & $\begin{array}{l}\text { Ninkovic V, Olsson U, Pettersson J. Mixing barley cultivars affects aphid host plant } \\
\text { acceptance in field experiments. Entomologia Experimentalis et Applicata } \\
\text { 2002;102:177-82. }\end{array}$ \\
\hline
\end{tabular}




\begin{tabular}{|c|c|}
\hline 104. & $\begin{array}{l}\text { Birkett MA, Campbell CAM, Chamberlain K, Guerrieri E, Hick AJ, Martin JL, et al. } \\
\text { New roles for cis-jasmone as an insect semiochemical and in plant defense. } \\
\text { Proceedings of the National Academy of Science of the United States of America } \\
2000 ; 97: 9329-34 \text {. }\end{array}$ \\
\hline 105. & $\begin{array}{l}\text { Ninkovic V, Ahmed E, Glinwood R, Pettersson J. Effects of two types of } \\
\text { semiochemical on population development of the bird cherry oat aphid Rhopalosiphum } \\
\text { padi in a barley crop. Agricultural and Forest Entomology 2003;5:27-33. }\end{array}$ \\
\hline 106. & $\begin{array}{l}\text { Bruce TJA, Matthes MC, Chamberlain K, Woodcock CM, Mohib A, Webster B, et al. } \\
\text { cis-jasmone induces Arabidopsis genes that affect the chemical ecology of multitrophic } \\
\text { interactions with aphids and their parasitoids. Proceedings of the National Academy of } \\
\text { Sciences of the United States of America 2008; } 105: 4553-8 \text {. }\end{array}$ \\
\hline 107. & $\begin{array}{l}\text { James DG. Synthetic herbivore-induced plant volatiles as field attractants for beneficial } \\
\text { insects. Environmental Entomology } 2003 ; 32: 977-82 \text {. }\end{array}$ \\
\hline 108. & $\begin{array}{l}\text { Vallad GE, Goodman RM. Systemic acquired resistance and induced systemic } \\
\text { resistance in conventional agriculture. Crop Science } 2004 ; 44: 1920-34 \text {. }\end{array}$ \\
\hline 109. & $\begin{array}{l}\text { Papaj DR, Lewis AC. Insect Learning: Ecological and Evolutionary Perspectives. New } \\
\text { York, USA: Chapman \& Hall, Inc; } 1993 .\end{array}$ \\
\hline 110. & $\begin{array}{l}\text { De Boer JG, Dicke M. Olfactory learning by predatory arthropods. Animal Biology } \\
\text { 2006;56:143-55. }\end{array}$ \\
\hline 111. & $\begin{array}{l}\text { van Wijk M, De Bruijn PJA, Sabelis MW. Predatory mite attraction to herbivore- } \\
\text { induced plant odors is not a consequence of attraction to individual herbivore-induced } \\
\text { plant volatiles. Journal of Chemical Ecology } 2008 ; 34: 791-803 \text {. }\end{array}$ \\
\hline 112. & $\begin{array}{l}\text { Haley SD, Peairs FB, Walker CB, Rudolph JB, Randolph TL. Occurrence of a new } \\
\text { Russian wheat aphid biotype in Colorado. Crop Science 2004;44:1589-92. }\end{array}$ \\
\hline 113. & $\begin{array}{l}\text { Mumm R, Hilker M. Direct and indirect chemical defence of pine against folivorous } \\
\text { insects. Trends in Plant Science } 2006 ; 11: 351-8 \text {. }\end{array}$ \\
\hline 114. & $\begin{array}{l}\text { Degenhardt J, Gershenzon J, Baldwin IT, Kessler, A. Attracting friends to feast on } \\
\text { foes: engineering terpene emission to make crop plants more attractive to herbivore } \\
\text { enemies. Current Opinion in Biotechnology 2003;14:169-76. }\end{array}$ \\
\hline 115. & $\begin{array}{l}\text { Kos M, van Loon JJA, Dicke M, Vet LEM. Transgenic plants as vital components of } \\
\text { integrated pest management. Trends in Biotechnology 2009;27:621-27. }\end{array}$ \\
\hline 116. & $\begin{array}{l}\text { Unsicker SB, Kunert G, Gershenzon J. Protective perfumes: the role of vegetative } \\
\text { volatiles in plant defense against herbivores. Current Opinion in Plant Biology } \\
\text { 2009;12:479-85. }\end{array}$ \\
\hline
\end{tabular}

Table 1. Plants with modified volatile emission after transformation, and effects on herbivores and their natural enemies

\begin{tabular}{|c|c|c|c|}
\hline Modified plant & Trait changed & Effect & $\underline{\text { Reference }}$ \\
\hline & $\underline{\text { Terpenoids }}$ & & \\
\hline$\underline{\text { Arabidopsis }}$ & (3S)-E-Nerolidol $\uparrow$ & $\mathrm{N} \uparrow$ & [65] \\
\hline
\end{tabular}




\begin{tabular}{|c|c|c|c|}
\hline & (E)-DMNT & & \\
\hline Arabidopsis & TPS10 terpenes $\uparrow$ & $\mathrm{N} \uparrow$ & [66] \\
\hline$\underline{\text { Arabidopsis }}$ & $(E)-\beta$-farnesene $\uparrow$ & $\begin{array}{ll}\mathrm{H} \downarrow & \mathrm{N} \uparrow \\
\end{array}$ & [67] \\
\hline Maize & $\begin{array}{ll}(E)-\beta- & \uparrow \\
\text { caryophyllene } & \end{array}$ & $\mathrm{N} \uparrow$ & {$[681$} \\
\hline Arabidopsis & $\begin{array}{ll}\text { Linalool } & \uparrow \\
\text { (Nerolidol) } & \end{array}$ & $\underline{\mathrm{H} \downarrow}$ & [69] \\
\hline Tobacco & Isoprene & $\underline{\mathrm{H} \downarrow}$ & [70] \\
\hline Tobacco & Patchoulol & $\underline{\mathrm{H} \downarrow}$ & [71] \\
\hline Arabidopsis & Isoprene & $\begin{array}{ll}\mathrm{Hi} & \mathrm{N} \downarrow \\
\end{array}$ & [72] \\
\hline Wild tobacco & $\underline{\text { HI-sesquiterpenes } \downarrow}$ & $\underline{\mathrm{H} \uparrow \quad \mathrm{N} \downarrow}$ & {$[82,86]$} \\
\hline & $\underline{C_{6}}=\underline{G L V}$ & & \\
\hline$\underline{\text { Arabidopsis }}$ & $\underline{\text { HI-GLV }}$ & $\begin{array}{l}\mathrm{N} \uparrow \\
\end{array}$ & {$[74]$} \\
\hline$\underline{\text { Arabidopsis }}$ & HI-GLV & $\begin{array}{ll}\mathrm{Hi} & \mathrm{N} \uparrow \\
\end{array}$ & [85] \\
\hline$\underline{\text { Arabidopsis }}$ & HI-GLV & $\mathrm{N} \downarrow$ & [74] \\
\hline Wild tobacco & HI-GLV & $\underline{\mathrm{H} \downarrow} \quad \mathrm{N} \downarrow$ & {$[82,84]$} \\
\hline \multirow[t]{2}{*}{ Potato } & $\underline{\text { GLV }}$ & $\underline{\mathrm{H} \uparrow}$ & [83] \\
\hline & Others & & \\
\hline Arabidopsis & HI-Nitrile & $\begin{array}{ll}\mathrm{H} \downarrow & \mathrm{N} \uparrow \\
\end{array}$ & [75] \\
\hline
\end{tabular}

$\underline{\mathrm{H}}=$ herbivore, $\mathrm{N}=$ Natural enemy, $\mathrm{I}=$ induced, $\mathrm{TPS}=$ terpene synthase, $\mathrm{GLV}=\mathrm{C}_{6}$ green leaf $\underline{\text { volatiles }}$

$\underline{\uparrow}=$ increased $\downarrow=$ decreased $\mathrm{i}=$ indifferent 
Figure 1. Volatile plant signals that could be modified via plant breeding or used as artificial elicitors for improved direct and indirect resistance to arthropod pests.
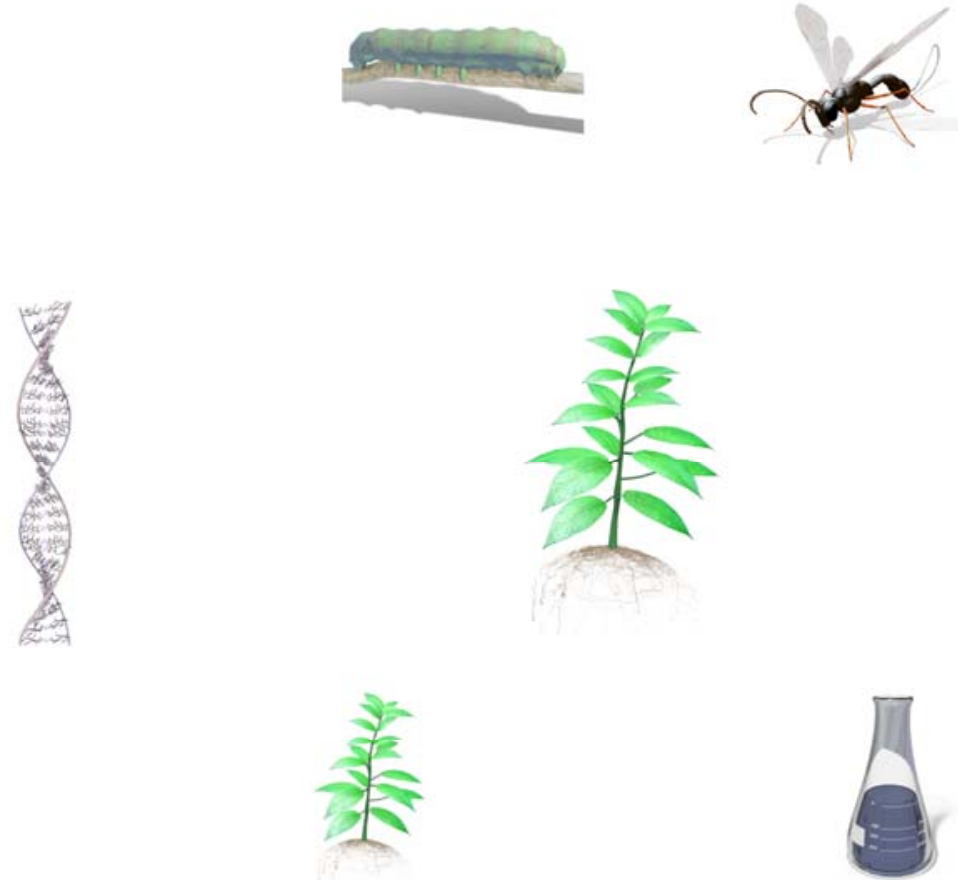